University at Albany, State University of New York

Scholars Archive

Atmospheric and Environmental Science

Faculty Scholarship

Atmospheric and Environmental Sciences

Spring 2019

\title{
Measurements of geomagnetic declination (1685-1910) using land surveys, LiDAR, and stone walls
}

John W. Delano PhD

University at Albany, State University of New York, jdelano@albany.edu

Follow this and additional works at: https://scholarsarchive.library.albany.edu/cas_daes_scholar

Part of the Geophysics and Seismology Commons

\section{Recommended Citation}

Delano, John W. PhD, "Measurements of geomagnetic declination (1685-1910) using land surveys, LiDAR, and stone walls" (2019). Atmospheric and Environmental Science Faculty Scholarship. 5.

https://scholarsarchive.library.albany.edu/cas_daes_scholar/5

This Article is brought to you for free and open access by the Atmospheric and Environmental Sciences at Scholars Archive. It has been accepted for inclusion in Atmospheric and Environmental Science Faculty Scholarship by an authorized administrator of Scholars Archive. For more information, please contact scholarsarchive@albany.edu. 


\section{Measurements of geomagnetic declination (1685-1910) using land surveys, LiDAR, and stone walls}

\section{John W. Delano}

Dept. of Atmospheric and Environmental Sciences, State University of New York at Albany, Albany, NY 12222 USA idelano@albany.edu

\section{Key Points:}

- 1200 kilometers of boundaries surveyed in 1685-1910 and marked by stone walls were measured using LiDAR (Light Detection and Ranging) images

- With the exception of lower declinations (i.e., 1.5 degrees eastward) in 1775-1810, the results are in good agree with the gufm1 and IGRF12 geomagnetic field models

- When associated with accurate land surveys, durable, human-engineered structures on land (e.g., stone walls; roads) contain information about geomagnetic declination

Journal of Geophysical Research-Solid Earth (in press)

January 2019

DOI: 10.1029/2018JB016655 


\begin{abstract}
Nearly 1200 kilometers of boundaries surveyed in 1685-1910, upon which stone walls were subsequently built, were measured using high-resolution LiDAR (Light Detection and Ranging) in the northeastern United States (New Hampshire and New York). The geomagnetic declinations at the time of the original land surveys of those stone wall-defined boundaries have been determined and compared with (i) current geophysical models (i.e., gufm1, IGRF12; United States Historical Declinations-USHD), and (ii) measured declinations (Bauer, 1902). With the exception of lower declinations (i.e., $1.5^{\circ}$ eastward) in 1775-1810, the results of this study are in good agreement with gufm 1 and IGRF12 geomagnetic declinations. This study yielded systematically higher declinations (i.e., up to $2.0^{\circ}$ westerly) than the USHD values during 1750 1780. These results demonstrate that geomagnetic declination can be determined when durable, human-engineered structures on land (e.g., stone walls; roads) are accompanied by detailed historical documentation and accurate land surveys. An example of using old streets (1699) in Colonial Williamsburg, VA is also discussed. Precisions of the bearings along boundaries in the $17^{\text {th }}-19^{\text {th }}$ century land surveys used this study were typically better than $\pm 0.30^{\circ}$.
\end{abstract}

\title{
1 Introduction
}

Permanent settlements by Europeans began in the northeastern United States in the early $17^{\text {th }}$ century (e.g., English at Jamestown, Virginia in 1607; English at Plymouth, Massachusetts in 1620; Dutch at Albany, New York in 1635). As the European population increased, new settlements were formed further inland to the west. Since the principal occupation of the European settlers was farming, the land was cleared of the primeval forests for the purposes of grazing livestock and planting crops. The boundaries of settlers' properties, which were commonly 100-or-more acres in extent, were defined by survey teams using magnetic compasses and Gunter chains. The diary of Matthew Patten, who was in charge of a survey in 1752-1753, described the daily challenges of rough terrain and harsh weather as his team of axmen, chainmen, and surveyors laid out 242 lots in $100 \mathrm{~km}^{2}$ of wilderness in Henniker, NH (Cogswell, 1880). Survey reports and detailed historical information were collected during the current investigation for selected areas of the northeastern United States (Figure 1; Appendix I) to determine when-and-where boundaries were established.

Since the northeastern United States was glaciated during the Pleistocene, the abundance of rocks in the soils was a major challenge for farmers when preparing their fields for cultivation. Those rocks were moved to the edges of the fields, some of which were the surveyed boundaries of the properties, to form an estimated $400,000 \mathrm{~km}$ of stone walls (by the late $19^{\text {th }}$ century), principally in New York and New England (Allport, 1990; Bowles, 1939; Primack, 1969; Thorson, 2002). When regions further west of New York and New England with rock-free soils became available for European settlement in the early $19^{\text {th }}$ century, large numbers of the old farms in New York and New England were abandoned by their owners (Barron, 1984; Foster, 1992; Harrison, 2005; Raup \& Carlson, 1941). Within a few decades of those abandonments, forests reclaimed the previously cleared areas. As a result, old stone walls are now a common feature in the vast rural forests of the northeastern United States (Figures 2a,b). Although those old stone walls are seldom visible from the air due to their now being obscured by the overlying forest canopy, they are readily visible in LiDAR (Light Detection and Ranging) images having resolutions of 1-meter-or-better (Figure 2c; Johnson \& Ouimet, 2014, 2016). LiDAR technology involves an airborne platform with instruments that emit up to 150,000 laser pulses 
per second. The round-trip travel-times and location of the pulses are measured to derive an image of the topography without obscuration by the overlying forest canopy (digital deforestation).

In summary, it is important to emphasize that the relevant time-parameter in the current investigation was the year when the boundaries were originally established by survey teams using magnetic compasses, not when stone walls were subsequently built upon those pre-existing boundaries. The results of this study have been compared with the predictions of the NCEI declination calculator (https://www.ngdc.noaa.gov/geomag-web/\#declination), which are based on the gufm 1 model (Jackson et al., 2000; Jonkers et al., 2003) for the years 1590-1900, the International Geomagnetic Reference Field model (IGRF12: Thebault et al., 2015) for the years 1900-2020, and with the United States Historical Declination model (USHD; https://www.ngdc.noaa.gov/geomag-web/\#ushistoric).

Figure 1: Locations of regions in New Hampshire, New York, and Virginia. Multiple sites are contained within some of the stars. The distance between Williamsburg, VA (southern-most location) and Vermontville, NY (northern-most location) is $830 \mathrm{~km}$. This figure is modified after https://www.maps.com/east-coast-usa-wall-map.html

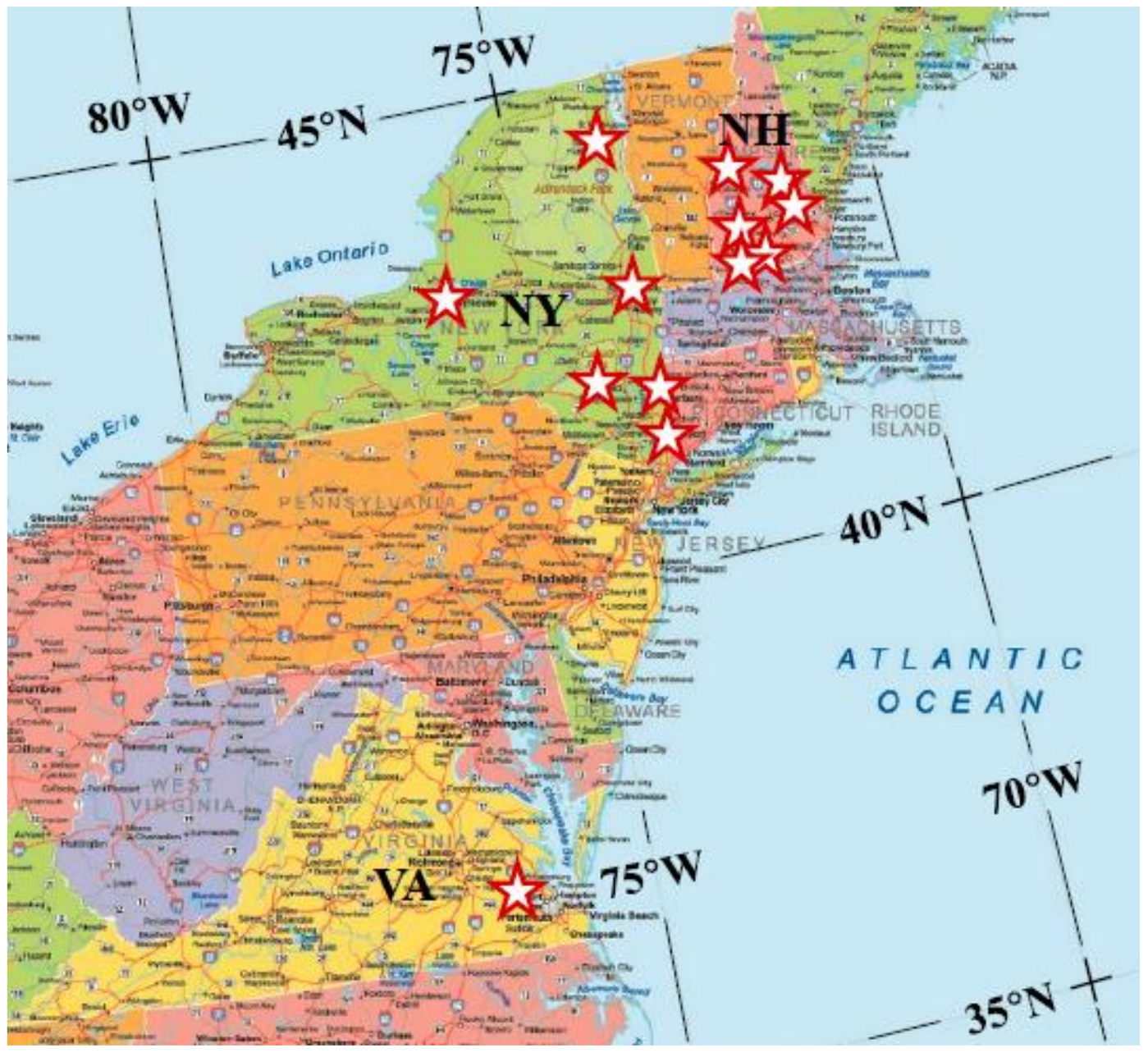


Figure 2: $(\mathrm{a}, \mathrm{b})$ Old stone walls in a heavily forested area of Grafton, $\mathrm{NY}\left(42.781^{\circ} \mathrm{N}\right.$, $73.433^{\circ} \mathrm{W}$ ), and (c) their appearance in a LiDAR image (18TXN270375). The width and height of these stone walls are typically 1.5-meter and 0.5-0.8 meter, respectively. Other linear features in the LiDAR image are additional stone walls beneath the forest canopy of this abandoned $18^{\text {th }}$ $19^{\text {th }}$ century farmland. Shades of gray in the LiDAR image reflect the 20-meter range in elevation. The brighter areas have higher elevations than the darker areas.

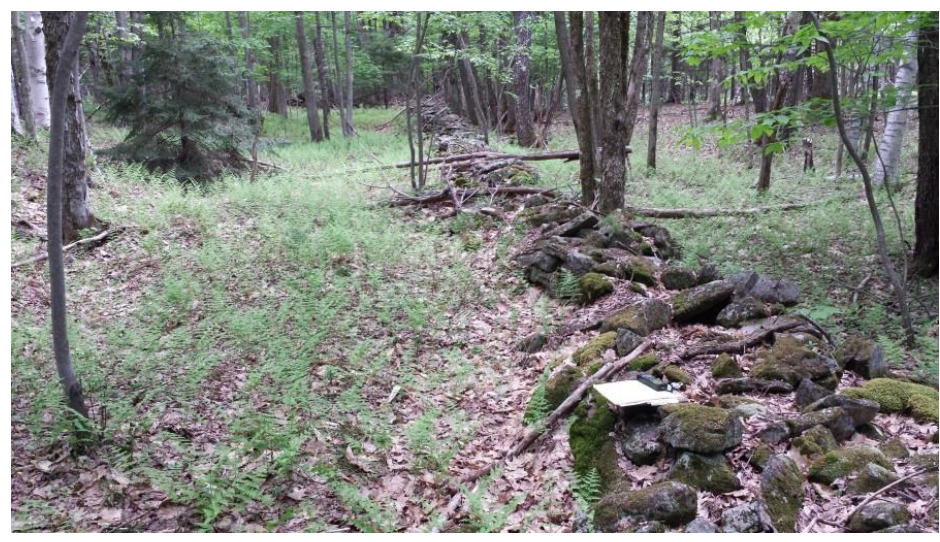

(a)

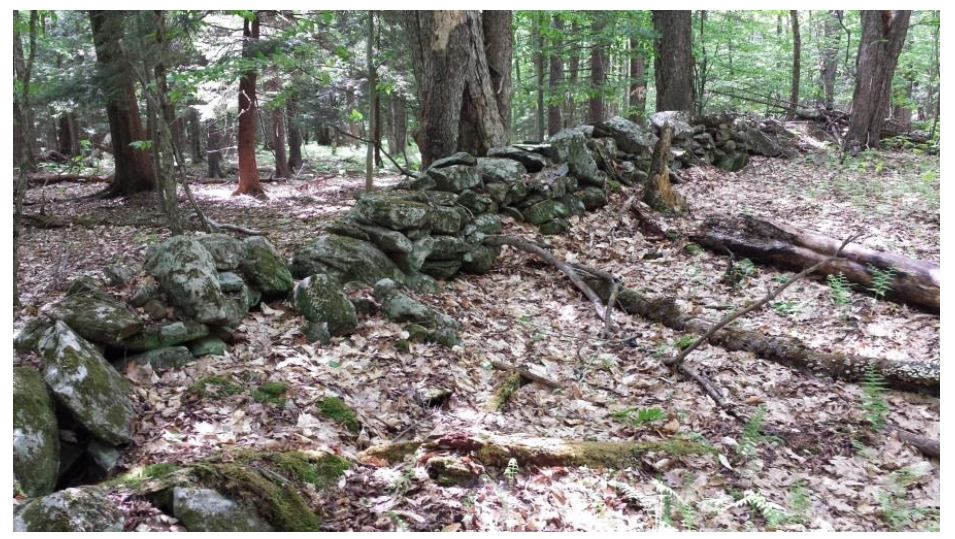

(b)

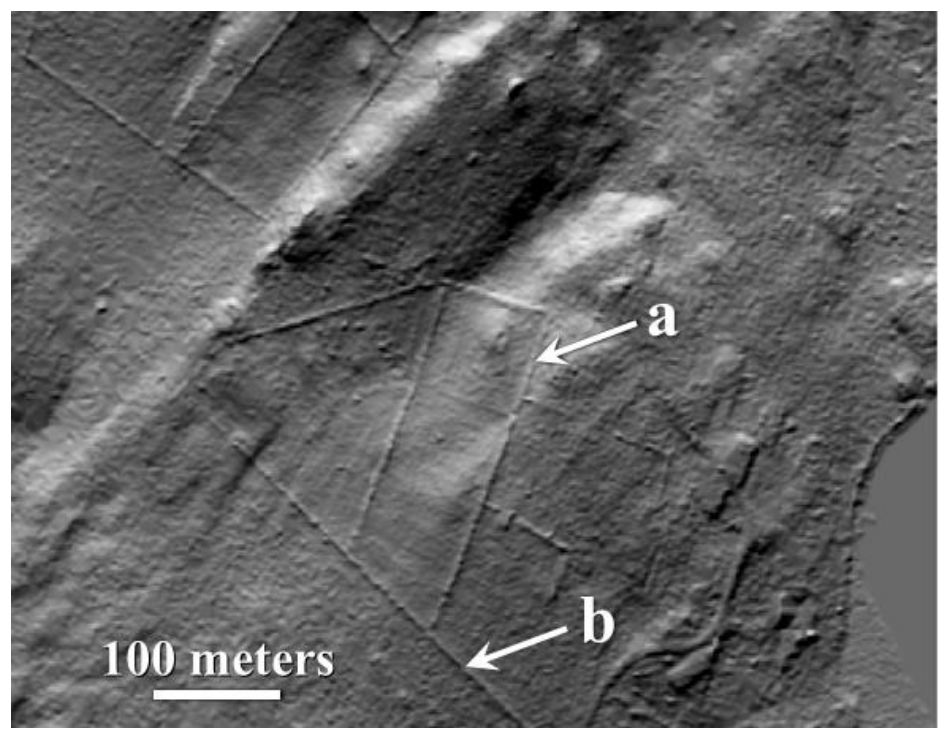

(c) 


\section{Materials and Methods}

Two principal sources of information were used in this study to constrain magnetic declinations: $17^{\text {th }}-19^{\text {th }}$ century surveyors' reports at the New York State Archives, New Hampshire State Archives, and other sources cited in Appendices I-IV of this work; and publicly available LiDAR images of the studied regions acquired by State and Federal agencies. The LiDAR images were processed using ArcMap 10.5.1 software by ArcGIS. The data listed in Appendices II-IV identify one LiDAR image per boundary that is representative of the stone wall lying along that boundary. An entire length of a boundary continued along several adjacent LiDAR images.

$17^{\text {th }}-19^{\text {th }}$ century land surveys of large tracts of land (from 100 acres to 100,000 acres) were used that showed (i) simple boundary-geometries (e.g., quadrilateral), (ii) the date of the survey, and (iii) magnetic bearings of the property boundaries at the time of the land survey. LiDAR images of the area were processed to search for stone walls along the surveyed boundaries. When those stone walls were found, multiple points of latitude and longitude along those walls were obtained from the digital LiDAR images, each of which covered $2.3 \mathrm{~km}^{2}$. Linear correlation coefficients of latitude and longitude along all stone wall-defined boundaries with lengths $>5 \mathrm{~km}$ were $>0.999$. Geomagnetic declination is the difference between (i) the bearing of the boundary with respect to magnetic North at the time of the land survey and (ii) the bearing of that boundary with respect to True North measured in the LiDAR image. By convention, geomagnetic declination has a positive (negative) value when magnetic North is east (west) of True North. The geomagnetic declinations determined in this study were compared with the values obtained from the NCEI declination calculator that uses two geomagnetic models. The 'gufm1' model (Jackson et al., 2000; Jonkers et al., 2003) describes worldwide geomagnetic declinations during the interval 1590-1900. The International Geomagnetic Reference Field (IGRF12) of Thebault et al. (2015) describes worldwide geomagnetic declinations from 1900 onwards. Model predictions from gufm1 and IGRF12 are available at the National Centers for Environmental Information (NCEI) website: https://www.ngdc.noaa.gov/geomag-web/\#declination. The geomagnetic declinations determined in this study were also compared with the United States Historic Declination model (USHD) from the year 1750, which is also available at the NCEI website: https://www.ngdc.noaa.gov/geomag-web/\#ushistoric.

The approach described in this paper to infer geomagnetic declination requires the availability of (i) accurate land surveys of known age, (ii) durable, human-engineered topographic features along surveyed boundaries, and (iii) high-resolution LiDAR images. High-resolution LiDAR images are often available on-line and can be processed on personal computers using ArcMap software available from ArcGIS.

The bearings with respect to True North measured on larger lengths had better precisions than bearings measured on shorter lengths. Figure 3 shows results for 38 boundaries (Appendix III) laid out in the 1768-1769 survey totaling nearly $202 \mathrm{~km}$ in Stoddard, $\mathrm{NH}\left(43.073^{\circ} \mathrm{N}\right.$; $72.120^{\circ} \mathrm{W}$ ). The lengths and inferred declinations of these 38 boundaries were used to determine the length-weighted mean for the magnetic declination in $1768-1769\left(7.64^{\circ} \mathrm{W}\right)$. Figure 3 shows that the 38 absolute values of deviations from that length-weighted mean decreased as the measured lengths of the boundaries increased. The sum of absolute values among the lengthweighted deviations from the length-weighted mean for these 38 measured boundaries was $0.33^{\circ}$ 
(Figure 3; Appendix III). Root-mean-square (rms) values for the declinations are also listed in Appendices II-III.

Points of latitude and longitude measured along each of the stone wall-defined boundaries with lengths $>5 \mathrm{~km}$ consistently yielded linear correlation coefficients $>0.999$ at all localities examined in New Hampshire and New York during this study. Twenty (20) of the 38 boundaries measured in this study at Stoddard, NH had lengths greater than $5.0 \mathrm{~km}$ (Figure 3; Appendix III). Those 20 boundaries comprise $71 \%$ of the total lengths $(144 \mathrm{~km}$ of $202 \mathrm{~km}$ ) measured in Stoddard, NH and yielded a length-weighted declination of $7.65^{\circ} \mathrm{W}$ with an absolute value for the length-weighted deviation of $0.27^{\circ}$. As is evident from inspection of Figure 3 , the bearings among the 20 boundaries with lengths $>5 \mathrm{~km}$ generally had smaller deviations than the 18 stone wall-defined boundaries with lengths $<5 \mathrm{~km}$. Although $5 \mathrm{~km}$ is an arbitrary length, Figure 3 shows the intuitively obvious point that the bearings of longer linear segments should generally have smaller deviations from the length-weighted mean than those of shorter linear segments.

Figure 3. The lengths and absolute values of deviations from the length-weighted mean of declination $\left(7.65^{\circ} \mathrm{W}\right)$ in $1768-1769$ of the 38 stone wall-defined boundaries $(202 \mathrm{~km})$ measured in Stoddard, NH $\left(43.073^{\circ} \mathrm{N} ; 72.120^{\circ} \mathrm{W}\right.$; Appendix III). The sum of length-weighted deviations from the length-weighted mean for all 38 values is $0.33^{\circ}$ (horizontal dashed line). The vertical dashed line identifies the 20 boundaries measured in this study having lengths greater than $5 \mathrm{~km}$.

\section{Stoddard, $\mathrm{NH}$}

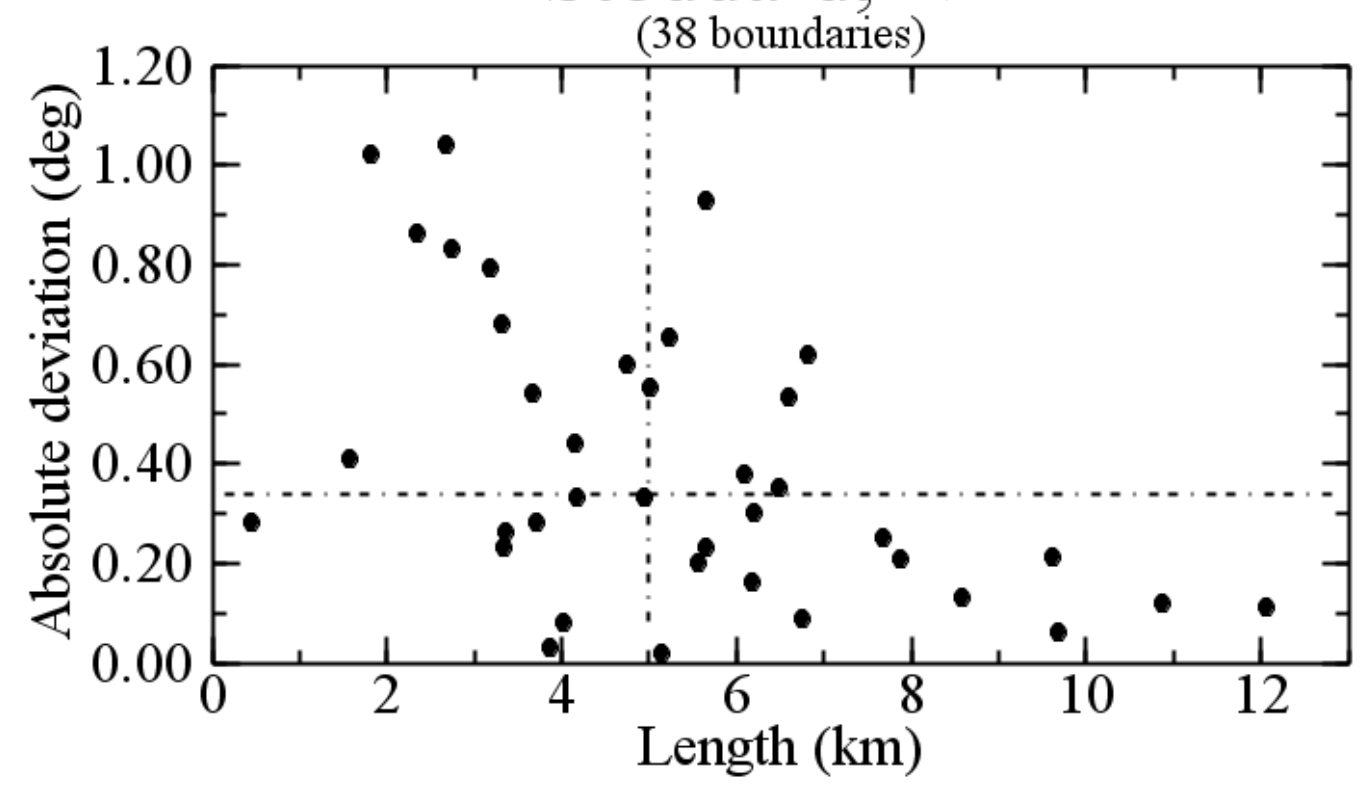

\section{Results}

This study examined $1200 \mathrm{~km}$ of stone wall-defined boundaries associated with old land surveys in 22 regions in the States of New Hampshire and New York (Figure 1), as well as old streets in Colonial Williamsburg, Virginia (Figure 1). Four examples of this approach are described in the following section (Stoddard, NH; Rensselaerwyck Manor near Medusa, NY; 'Oblong Line' near 
Wingdale, NY; Colonial Williamsburg, VA). Historical information (Appendix I) and the list of data for all of the localities in New York (Appendix II), New Hampshire (Appendix III), and Virginia (Appendix IV) measured in this study are available at the URL provided in the Acknowledgements. A summary of the results are contained in Table 1.

\subsection{Western Rensselaerwyck Manor near Medusa, New York $\left(42.464^{\circ} \mathrm{N} ; 74.094^{\circ} \mathrm{W}\right)$}

The Rensselaerwyck Manor was a vast tract of land (700,000 acres) lying on both the eastern and western sides of the Hudson River. It was granted to Kiliaean Van Rensselaer by the Dutch West India Company in 1629-1630 (Nissenson, 1937; Sylvester, 1880). Following the end of the Revolutionary War in 1783, and in preparation for settlement, a portion of the western Manor in southern New York (Figure 1) was surveyed in 1787 by a team headed by William Cockburn (1736-1810) using a magnetic compass. Several hundred quadrilateral-shaped lots ( 175 acres each) were defined by an orthogonal grid having the magnetic bearings in 1787 of $N 85^{\circ} 40^{\prime} E$ and N04 $20^{\prime} W$ (Figures 4a-d: New York State Archives: SC7079a, Map 12 SE and Map 12 SW). Figure 4a shows a portion of the 1787 survey map. The grid laid out by those surveyors in 1787 is currently well-defined by old stone walls (Figures $4 \mathrm{c}, \mathrm{d}$ ). The current study measured nearly $192 \mathrm{~km}$ of those stone wall-defined boundaries using high-resolution LiDAR images (Appendix II).

Using the length-weighted values described in the Section 2, the skill of Cockburn's survey team in 1787 is demonstrated in part by the high-level of precision (with respect to True North; Figure 4d) of that grid: $N 80^{\circ} 22 \pm 8^{\prime} E(100 \mathrm{~km})$ and $N 9^{\circ} 26 \pm 7^{\prime} W(92 \mathrm{~km})$. Those results yielded a length-weighted mean and sum of absolute values of deviations from the length-weighted mean for the magnetic declination in 1787 in this region of $5.28 \pm 0.11^{\circ} \mathrm{W}$ (Table 1; Appendix II).

Table 1: Summary of results showing locations, dates, lengths of stone wall-defined boundaries, geomagnetic declinations inferred in this study, and comparisons with the gufm 1 and IGRF12 models (and United States Historical Declination (USHD). Since USHD values earlier than

1750 do not exist, 'nd' is shown in the $\triangle$ USHD column for dates prior to 1750 . Refer to

Appendix I for historical background on each location, and Appendices II-IV for the data. Millerton, Dover Plains, Sears Corners, and Lewisboro are towns in New York near the Oblong Line.

$\begin{array}{cccccccc}\text { NEARBY } & & & & & & & \\ \text { TOWNSHIP } & \text { Latitude } & \text { Longtitude } & \text { Year } & \text { Length }(\mathbf{k m}) & \text { Declination } & \Delta \text { gufm1 } & \Delta \text { USHD } \\ \text { GRAFTON } & 42.814^{\circ} \mathrm{N} & 73.482^{\circ} \mathrm{W} & 1685 & 22.8 & 8.85 \pm 0.17^{\circ} \mathrm{W} & -0.62 & \text { nd } \\ \text { GRAFTON } & 42.814^{\circ} \mathrm{N} & 73.482^{\circ} \mathrm{W} & 1765 & 22.8 & 6.85 \pm 0.17^{\circ} \mathrm{W} & +0.38 & -0.66 \\ \text { GRAFTON } & 42.814^{\circ} \mathrm{N} & 73.482^{\circ} \mathrm{W} & 1787 & 22.8 & 5.25 \pm 0.17^{\circ} \mathrm{W} & +1.30 & +0.23 \\ \text { GRAFTON } & 42.814^{\circ} \mathrm{N} & 73.482^{\circ} \mathrm{W} & 1791 & 26.6 & 5.32 \pm 0.17^{\circ} \mathrm{W} & +1.23 & +0.09 \\ \text { GRAFTON } & 42.719^{\circ} \mathrm{N} & 73.473^{\circ} \mathrm{W} & 1791 & 2.98 & 5.18 \pm 0.30^{\circ} \mathrm{W} & +1.32 & +0.19 \\ \text { GRAFTON } & 42.719^{\circ} \mathrm{N} & 73.473^{\circ} \mathrm{W} & 1848 & 2.98 & 7.68 \pm 0.30^{\circ} \mathrm{W} & +0.14 & -0.07\end{array}$

STATE OF NEW YORK (668.3 $\mathrm{km}$ of boundaries) 


$\begin{array}{cccccccc}\text { BRUNSWICK } & 42.762^{\circ} \mathrm{N} & 73.597^{\circ} \mathrm{W} & 1788-91 & 13.7 & 5.33 \pm 0.23^{\circ} \mathrm{W} & +1.14 & -0.01 \\ \text { BRUNSWICK } & 42.774^{\circ} \mathrm{N} & 73.600^{\circ} \mathrm{W} & 1799 & 2.06 & 5.21 \pm 0.10^{\circ} \mathrm{W} & +1.07 & +0.12 \\ \text { GALEN } & 43.098^{\circ} \mathrm{N} & 76.896^{\circ} \mathrm{W} & 1798 & 40.2 & 2.75 \pm 0.05^{\circ} \mathrm{W} & +1.35 & +0.31 \\ \text { CARMEL } & 41.425^{\circ} \mathrm{N} & 73.762^{\circ} \mathrm{W} & 1754 & 57.5 & 7.45 \pm 0.36^{\circ} \mathrm{W} & -0.47 & -1.94 \\ \text { BEEKMAN } & 41.611^{\circ} \mathrm{N} & 73.713^{\circ} \mathrm{W} & 1716-17 & 11.3 & 7.79 \pm 0.20^{\circ} \mathrm{W} & +0.27 & \text { nd } \\ \text { HAVILAND } & 41.769^{\circ} \mathrm{N} & 73.894^{\circ} \mathrm{W} & 1699 & 47.5 & 7.76 \pm 0.17^{\circ} \mathrm{W} & -0.52 & \text { nd } \\ \text { MILLERTON } & 41.977^{\circ} \mathrm{N} & 73.527^{\circ} \mathrm{W} & 1731 & 16.2 & 9.09 \pm 0.10^{\circ} \mathrm{W} & +0.02 & \text { nd } \\ \text { DOVER PLAINS } & 41.753^{\circ} \mathrm{N} & 73.546^{\circ} \mathrm{W} & 1731 & 33.6 & 8.94 \pm 0.10^{\circ} \mathrm{W} & -0.06 & \text { nd } \\ \text { SEARS CORNERS } & 41.445^{\circ} \mathrm{N} & 73.573^{\circ} \mathrm{W} & 1731 & 35.0 & 8.57 \pm 0.10^{\circ} \mathrm{W} & 0 & \text { nd } \\ \text { LEWISBORO } & 41.256^{\circ} \mathrm{N} & 73.560^{\circ} \mathrm{W} & 1731 & 11.6 & 8.73 \pm 0.10^{\circ} \mathrm{W} & -0.35 & \text { nd } \\ \text { HARPERSFIELD } & 42.439^{\circ} \mathrm{N} & 74.687^{\circ} \mathrm{W} & 1768-71 & 50.1 & 5.93 \pm 0.16^{\circ} \mathrm{W} & +0.01 & -1.35 \\ \text { GREENVILLE } & 42.388^{\circ} \mathrm{N} & 74.000^{\circ} \mathrm{W} & 1768 & 60.1 & 5.34 \pm 0.37^{\circ} \mathrm{W} & +0.99 & +0.06 \\ \text { MEDUSA } & 42.465^{\circ} \mathrm{N} & 74.090^{\circ} \mathrm{W} & 1787 & 191.7 & 5.28 \pm 0.11^{\circ} \mathrm{W} & +0.59 & -0.50 \\ \text { VERMONTVILLE } & 44.451^{\circ} \mathrm{N} & 74.069^{\circ} \mathrm{W} & 1813 & 25.8 & 6.78 \pm 0.36^{\circ} \mathrm{W} & +0.22 & -0.20 \\ \text { PINE PLAINS } & 41.980^{\circ} \mathrm{N} & 73.656^{\circ} \mathrm{W} & 1743-44 & 19.5 & 7.80 \pm 0.13^{\circ} \mathrm{W} & +0.67 & \text { nd }\end{array}$

STATE OF NEW HAMPSHIRE

(503.5 km of boundaries)

\begin{tabular}{|c|c|c|c|c|c|c|c|}
\hline $\begin{array}{c}\text { NEARBY } \\
\text { TOWNSHIP }\end{array}$ & Latitude & Longtitude & Year & Length (km) & Declination & $\Delta$ gufm1 & $\Delta$ USHD \\
\hline HANOVER & $43.716^{\circ} \mathrm{N}$ & $72.189^{\circ} \mathrm{W}$ & $1764-8$ & 27.5 & $8.18 \pm 0.21^{\circ} \mathrm{W}$ & +0.82 & -0.64 \\
\hline HENNIKER & $43.172^{\circ} \mathrm{N}$ & $71.816^{\circ} \mathrm{W}$ & $1752-3$ & 66.4 & $9.71 \pm 0.22^{\circ} \mathrm{W}$ & -0.12 & -1.86 \\
\hline WILTON & $42.832^{\circ} \mathrm{N}$ & $71.772^{\circ} \mathrm{W}$ & $1762-3$ & 70.8 & $8.31 \pm 0.20^{\circ} \mathrm{W}$ & -0.05 & -1.17 \\
\hline WILTON & $42.832^{\circ} \mathrm{N}$ & $71.772^{\circ} \mathrm{W}$ & 1805 & 70.8 & $6.44 \pm 0.16^{\circ} \mathrm{W}$ & +1.08 & +0.54 \\
\hline WINDSOR & $43.114^{\circ} \mathrm{N}$ & $72.017^{\circ} \mathrm{W}$ & 1779 & 21.5 & $7.70 \pm 0.31^{\circ} \mathrm{W}$ & -0.06 & -0.93 \\
\hline NELSON & $43.007^{\circ} \mathrm{N}$ & $72.087^{\circ} \mathrm{W}$ & $1767-9$ & 62.4 & $7.94 \pm 0.17^{\circ} \mathrm{W}$ & -0.12 & -1.03 \\
\hline CANTERBURY & $43.297^{\circ} \mathrm{N}$ & $71.563^{\circ} \mathrm{W}$ & 1722 & 2.54 & $7.70 \pm 0 .{ }^{\circ} \mathrm{W}$ & -0.03 & nd \\
\hline CANTERBURY & $43.297^{\circ} \mathrm{N}$ & $71.563^{\circ} \mathrm{W}$ & 1800 & 2.54 & $10.7 \pm 0 .{ }^{\circ} \mathrm{W}$ & +0.63 & -0.21 \\
\hline BOSCAWEN & $43.329^{\circ} \mathrm{N}$ & $71.718^{\circ} \mathrm{W}$ & 1733 & 5.44 & $11.0 \pm 0 .{ }^{\circ} \mathrm{W}$ & +0.10 & nd \\
\hline BOSCAWEN & $43.329^{\circ} \mathrm{N}$ & $71.718^{\circ} \mathrm{W}$ & 1760 & 5.44 & $9.03 \pm 0 .{ }^{\circ} \mathrm{W}$ & +0.02 & -1.35 \\
\hline BOSCAWEN & $43.329^{\circ} \mathrm{N}$ & $71.718^{\circ} \mathrm{W}$ & 1781 & 11.6 & $8.14 \pm 0 .{ }^{\circ} \mathrm{W}$ & -0.07 & -0.99 \\
\hline RICHMOND & $42.715^{\circ} \mathrm{N}$ & $72.045^{\circ} \mathrm{W}$ & 1825 & 33.6 & $7.47 \pm 0 .{ }^{\circ} \mathrm{W}$ & +0.39 & +0.03 \\
\hline STODDARD & $43.073^{\circ} \mathrm{N}$ & $72.120^{\circ} \mathrm{W}$ & $1768-9$ & 201.8 & $7.64 \pm 0.33^{\circ} \mathrm{W}$ & +0.21 & -0.72 \\
\hline STODDARD & $43.073^{\circ} \mathrm{N}$ & $72.120^{\circ} \mathrm{W}$ & 1829 & 4.94 & $8.69 \pm 0 .{ }^{\circ} \mathrm{W}$ & -0.39 & -0.73 \\
\hline STODDARD & $43.073^{\circ} \mathrm{N}$ & $72.120^{\circ} \mathrm{W}$ & 1837 & 9.68 & $8.83 \pm 0 .{ }^{\circ} \mathrm{W}$ & +0.01 & -0.32 \\
\hline STODDARD & $43.073^{\circ} \mathrm{N}$ & $72.120^{\circ} \mathrm{W}$ & 1844 & 4.94 & $9.69 \pm 0 . \_{ }^{\circ} \mathrm{W}$ & -0.50 & -0.69 \\
\hline STODDARD & $43.073^{\circ} \mathrm{N}$ & $72.120^{\circ} \mathrm{W}$ & 1858 & 4.94 & $10.2 \pm 0 .{ }^{\circ} \mathrm{W}$ & -0.14 & -0.19 \\
\hline STODDARD & $43.073^{\circ} \mathrm{N}$ & $72.120^{\circ} \mathrm{W}$ & 1874 & 1.11 & $10.5 \pm 0 .{ }^{\circ} \mathrm{W}$ & +0.54 & +0.50 \\
\hline \multirow[t]{2}{*}{ STODDARD } & $43.073^{\circ} \mathrm{N}$ & $72.120^{\circ} \mathrm{W}$ & 1910 & 1.11 & $13.0 \pm 0 .{ }^{\circ} \mathrm{W}$ & $(+0.31 * *)$ & +0.26 \\
\hline & \multicolumn{7}{|c|}{ (** Delta IGRF12 model) } \\
\hline TOWNSHIP & Latitude & Longtitude & Year & Length $(\mathbf{k m})$ & Declination & $\Delta$ gufm1 & $\Delta$ USHD \\
\hline VILLIAMSBURG & $37.273^{\circ} \mathrm{N}$ & $76.692^{\circ} \mathrm{W}$ & 1699 & 2.21 & $3.32 \pm 0.05^{\circ} \mathrm{W}$ & +0.32 & nd \\
\hline
\end{tabular}


Figure 4: Area in the vicinity of Medusa, NY $\left(42.465^{\circ} \mathrm{N}, 74.090^{\circ} \mathrm{W}\right)$. (a) Small portion of the 1787 survey map by William Cockburn showing nine lots containing about 175 acres each. According to Cockburn, the orthogonal boundaries throughout the surveyed region had magnetic bearings in 1787 of $\mathrm{N}^{\circ} 45^{\circ} \mathrm{E}$ and $\mathrm{N} 04^{\circ} 20^{\prime} \mathrm{W}$. (b) Standard aerial image of the same area shown in 'a' from Google Earth centered on Lot No. 151. The yellow lines define the area contained in the LiDAR image. (c) LiDAR image, u_5700070250_2_meter, showing many linear stone walls in area 'b'. (d) Overlay of 1787 survey boundaries onto stone walls. Lot \#151 measures 808 x870 meters. The bearings with respect to True North along $192 \mathrm{~km}$ of stone walls measured in the region of Medusa, $\mathrm{NY}$ are $\mathrm{N} 80^{\circ} 22 \pm 8^{\prime} \mathrm{E}$ and $\mathrm{N} 09^{\circ} 26 \pm 7^{\prime} \mathrm{W}$. The inferred magnetic declination at this location in 1787 is $5.28 \pm 0.11^{\circ} \mathrm{W}$.

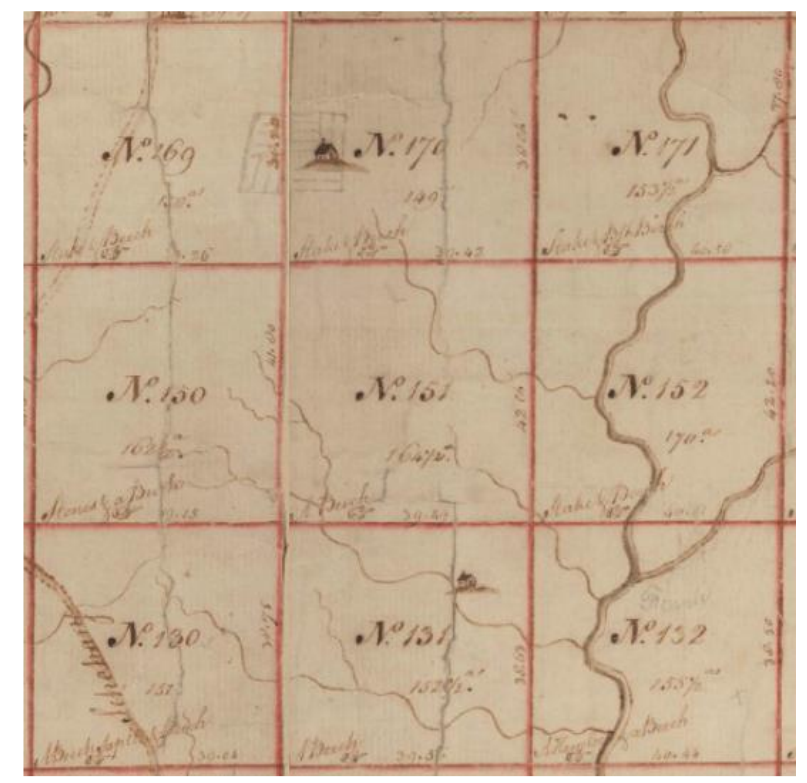

(a)

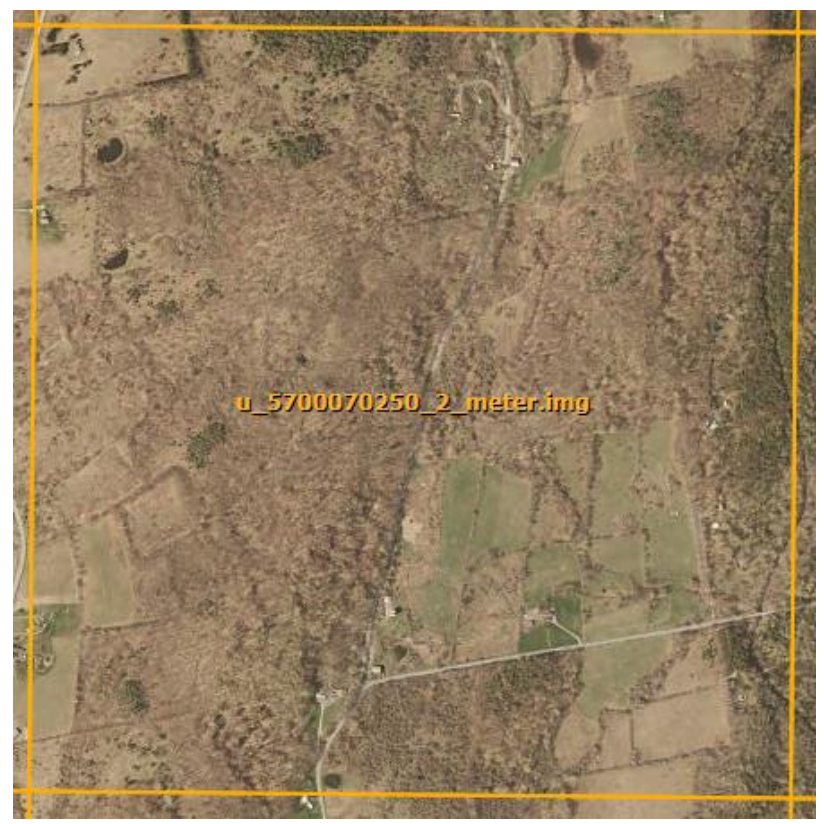

(b) 


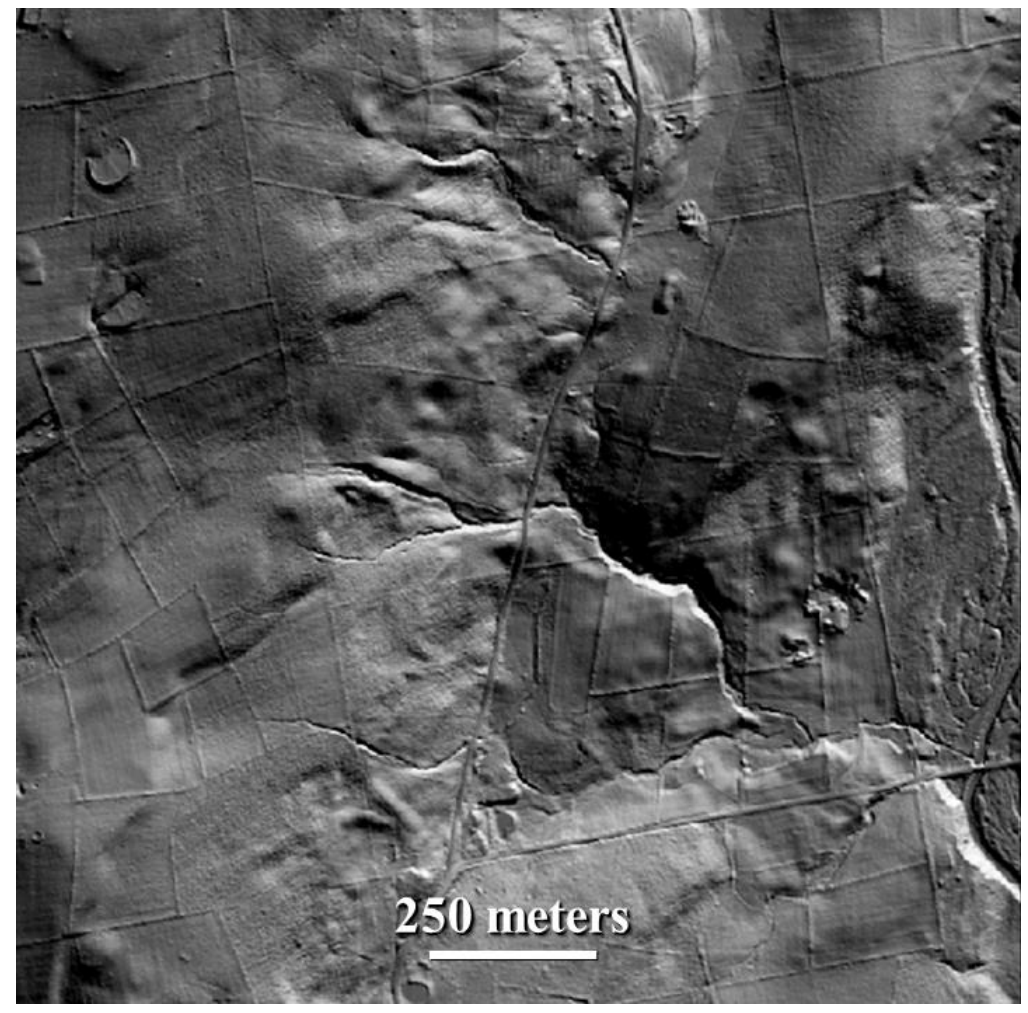

(c)

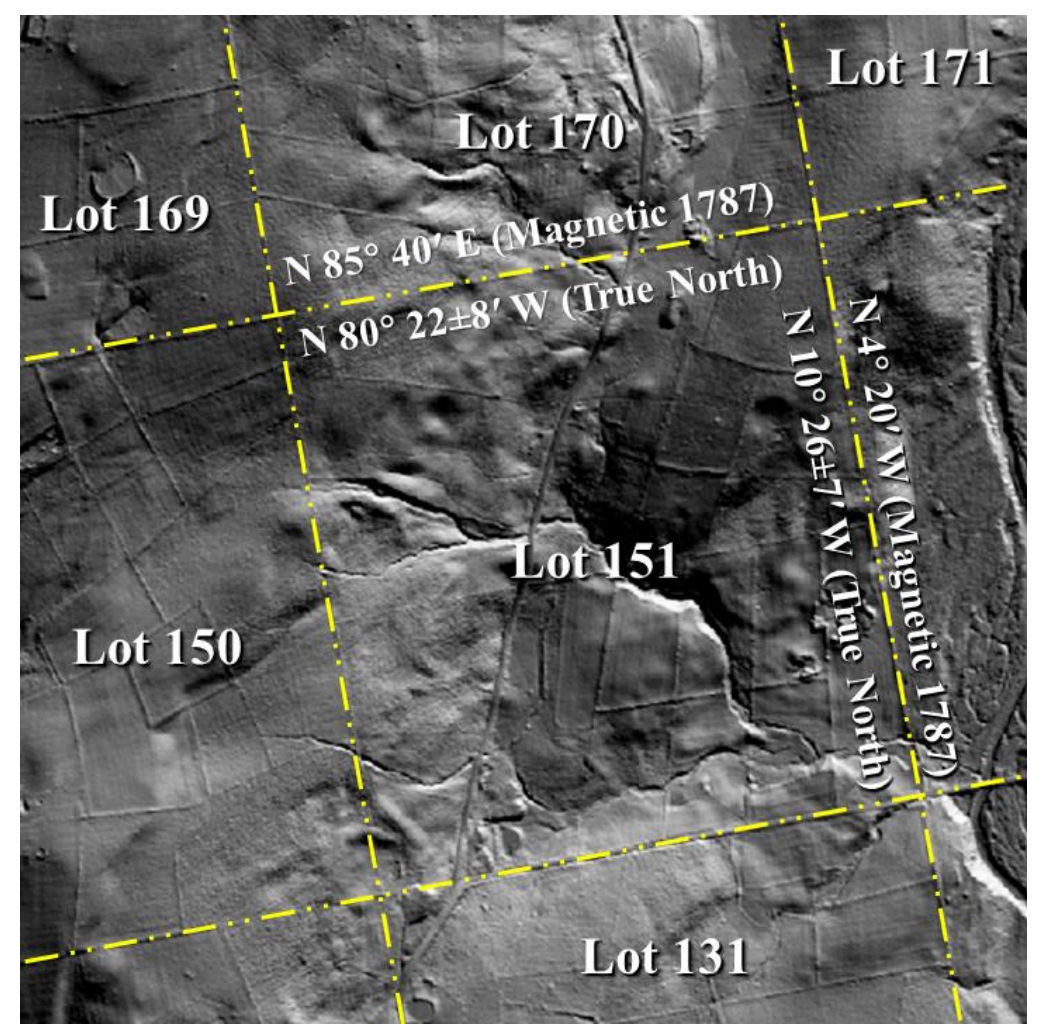

(d) 


\subsection{Township of Stoddard, New Hampshire $\left(43.073^{\circ} \mathrm{N} ; 72.120^{\circ} \mathrm{W}\right)$}

The $18^{\text {th }}$ century history of Stoddard, NH is summarized in Appendix I (Batchellor, 1896b; Gould, 1897; Hurd, 1886; Proper, 1974; Wilson, 1974). This township, which contains nearly 36,000 acres, was originally surveyed by magnetic compass in 1768-1769 (Appendix I). Nearly 400 quadrilateral-shaped lots were defined in that survey using boundaries that extended across the entire township with the following magnetic-bearings in 1768-1769: $N 80^{\circ} \mathrm{W}$ and $N 14^{\circ} \mathrm{E}$.

More than $200 \mathrm{~km}$ of stone-wall-defined boundaries along the 1768-1769 grid within this township were measured in the LiDAR images (Appendix III). The bearings with respect to True North and combined lengths of those measured boundaries in the grid were $N 87.8 \pm 0.5^{\circ} \mathrm{W}$ $(121 \mathrm{~km})$ and $N 6.5 \pm 0.4^{\circ} \mathrm{W}(81 \mathrm{~km})$. The length-weighted mean and the sum of absolute values for deviations from the length-weighted mean for the 38 boundaries measured in Stoddard, $\mathrm{NH}$ yielded a geomagnetic declination in $1768-1769$ of $7.6 \pm 0.3^{\circ} \mathrm{W}$ (Figure 3; Appendix III).

In addition to the 1768-1769 survey, Stoddard was unique in having had a highly motivated historian and professional surveyor, Charles L. Peirce (1874-1963), who compiled a detailed map (Map 256 at New Hampshire State Archives; http://www.stoddardnh.org/history/pages/charlespeirce-maps-of-stoddard) showing stone wall-defined boundaries that were surveyed in 1829, 1837, 1844, 1858, 1874, and 1910 (Appendix III). Those boundaries were located in the LiDAR images during this study to infer the magnetic declinations at the times of those surveys (Table 1). As a result, values for the geomagnetic declination at those times in the town of Stoddard, $\mathrm{NH}$ were obtained, but the deviations are only estimated since the lengths of the stone walldefined boundaries were small. When the results from Stoddard are combined with those from neighboring townships (Henniker, Nelson, Windsor; Appendix III), excellent agreement with the NCEI calculator for the gufm1 (prior to the year 1900) and IGRF12 (from 1900 onwards) models is observed (Figure 5).

Figure 5: Inferred magnetic declinations in this study among four nearby towns in New Hampshire: Henniker $\left(\mathrm{H}: 43.172^{\circ} \mathrm{N}, 71.816^{\circ} \mathrm{W}\right)$, Nelson $\left(\mathrm{N}: 43.007^{\circ} \mathrm{N}, 72.087^{\circ} \mathrm{W}\right)$, Stoddard (S: $43.073^{\circ} \mathrm{N}, 72.120^{\circ} \mathrm{W}$ ), and Windsor $\left(\mathrm{W}: 43.114^{\circ} \mathrm{N}, 72.017^{\circ} \mathrm{W}\right.$ ) compared with the gufm 1 (prior to 1900) and IGRF12 (from 1900 onwards) models (red curve). The vertical bars are the sum of the length-weighted deviations from the length-weighted means for each of the four oldest four points (Appendix III). The open circles are short segments of stone walls in Stoddard,

$\mathrm{NH}$ for which deviations could not be determined for lack of multiple boundaries (Section 2; Table 1). 


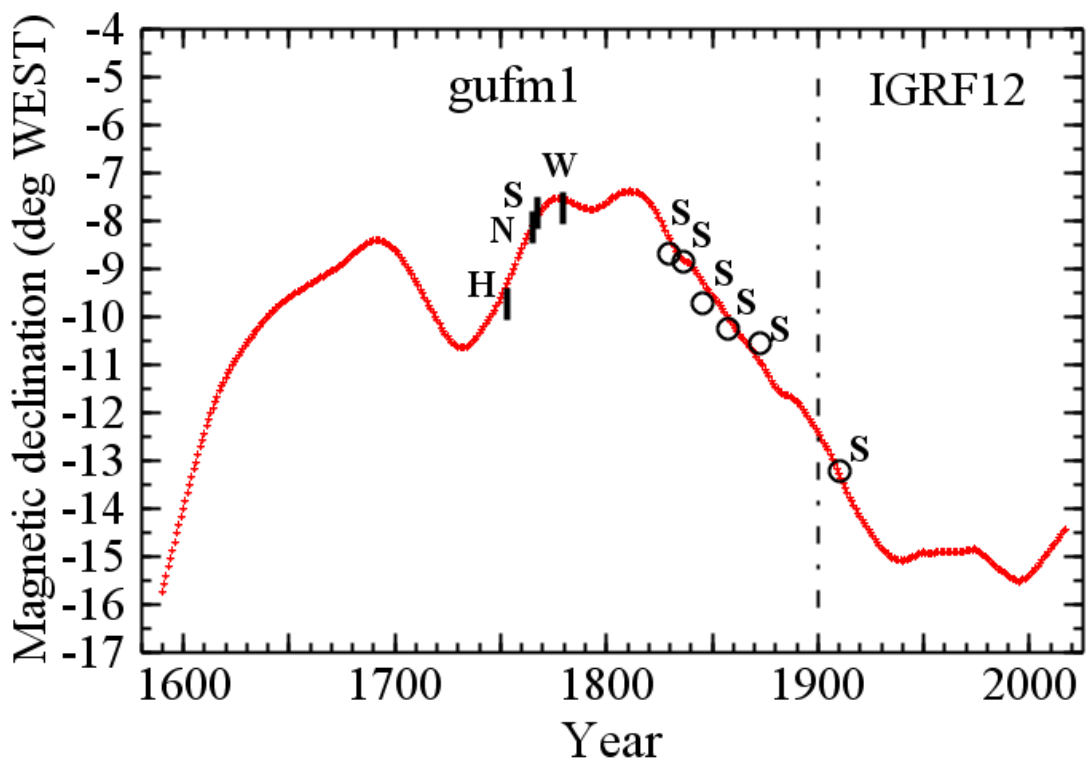

3.3 'Oblong Line' near Wingdale, New York (midpoint located at $41.673^{\circ} \mathrm{N}, 73.553^{\circ} \mathrm{W}$ )

The Oblong Line is a linear, 85-km boundary located $\sim 3 \mathrm{~km}$ west of the current border between New York and Connecticut (Figure 1) that formed the western boundary of a 61,440-acre tract of land in the early $18^{\text {th }}$ century. The history of the Oblong Line, which is provided in Appendix I, was surveyed in 1731 with a magnetic bearing along its entire length of $N 12^{\circ} 30^{\prime} E$ (Bowen, 1882; Buck \& McDermott, 1979; Gannett, 1900; Hasbrouck, 1909; Pelletreau, 1886; Smith, 1877; see Appendix II). Although stone walls along the 'Oblong Line' are now intermittent, segments were tracked in this study using LiDAR images at 64 locations for a distance of nearly $85 \mathrm{~km}$, which defined a line with a linear correlation coefficient for latitude and longitude of 0.9998 . The orientation of the Oblong Line with respect to True North was measured using LiDAR images (Appendix II) as being $N 03.7 \pm 0.3{ }^{\circ} \mathrm{E}$, which yields a magnetic declination at the midpoint of this boundary in 1731 of $8.8 \pm 0.3^{\circ} \mathrm{W}$. For comparison, the 1731 magnetic declination at this mid-point location using the gufm1 model (Jackson et al., 2000; Jonkers et al., 2003) is $8.8 \pm 0.5^{\circ} \mathrm{W}$. The USHD model does not extend to times earlier than 1750 .

A more detailed examination of the data along the Oblong Line in this study revealed an apparent change in the orientation along its $85-\mathrm{km}$ length with respect to True North (Figure 6). The orientation of stone wall segments ( $\geq 5 \mathrm{~km}$ in length) appears to change from $\mathrm{N} 03.2( \pm 0.3)^{\circ} \mathrm{E}$ (with respect to True North) at the northern end of the Oblong Line $\left(42.0498^{\circ} \mathrm{N}, 73.5215^{\circ} \mathrm{W}\right)$ to $\mathrm{N} 04.4( \pm 0.3)^{\circ} \mathrm{E}$ at the southern end $\left(42.2885^{\circ} \mathrm{N}, 73.5873^{\circ} \mathrm{W}\right)$. As a result, the stone walls along the Oblong Line appear to preserve a subtle change in the 1731 magnetic declination along the length of this boundary from $9.3( \pm 0.3)^{\circ} \mathrm{W}$ at the northern end to $8.1( \pm 0.3)^{\circ} \mathrm{W}$ at the southern end. As the 1731 survey team laid out the Oblong Line following their compass needle with a bearing of $\mathrm{N} 12^{\circ} 30^{\prime} \mathrm{E}$, their path (with respect to True North) gradually changed as they traversed isogonic lines.

Figure 6: Gradual change in the bearing of stone walls (with respect to True North) along 5$\mathrm{km}$ segments of the western boundary of the Oblong Patent $(84.8 \mathrm{~km})$ in New York State, which 
was surveyed in 1731. The linear least squares regression of these data $(y=0.0146 x+3.19$ $\mathrm{r}=0.70$ ) suggests that the bearing with respect to True North changes from about $\mathrm{N} 3.2^{\circ} \mathrm{E}$ at the northern end $\left(42.0498^{\circ} \mathrm{N}, 73.5215^{\circ} \mathrm{W}\right)$ to $\mathrm{N} 4.4^{\circ} \mathrm{E}$ at the southern end $\left(42.2885^{\circ} \mathrm{N}, 73.5873^{\circ} \mathrm{W}\right)$.

Since the magnetic compass-bearing in 1731 along the entire length of the Oblong Line was $\mathrm{N} 12.5^{\circ} \mathrm{E}$, the inferred declination in 1731 was about $9.3^{\circ} \mathrm{W}$ at the north end and about $8.1^{\circ} \mathrm{W}$ at the south end, in good agreement with the gufm 1 declinations in 1731 of $9.2^{\circ} \mathrm{W}$ and $8.4^{\circ} \mathrm{W}$ at the north and south ends, respectively.

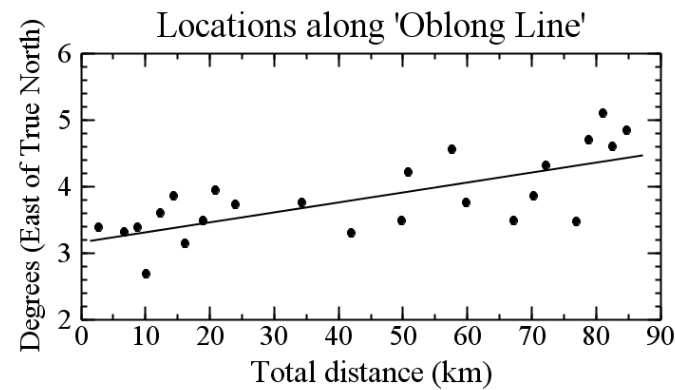

\subsection{Colonial Williamsburg, VA $\left(37.271^{\circ} \mathrm{N} ; 76.700^{\circ} \mathrm{W}\right)$}

Jamestown was established as the first permanent English settlement in North America in 1607 and became the first capitol of the Virginia Colony. When the Capitol Building in Jamestown was destroyed by fire in October 1698 (Hening, 1823; Tyler, 1907), the Royal Governor, Francis Nicholson, ordered (and the General Assembly agreed in April 1699, Act XIV; Hening, 1823) that the capitol be moved to "... Middle Plantation, seven miles from James Town (sic), in a healthier and more convenient place, and freer from the annoyance of mosquitoes" (Goodwin, 1980; Henning, 1823). That second capitol of the Virginia Colony was named Williamsburg (Hening, 1823), and is now the largest open-air museum in the world (Colonial Williamsburg Foundation, 2014; Kopper, 1986). In 1699, Theodorick Bland was commissioned by the Royal Governor to survey the 220-acre site (Goodwin, 1980; Tyler, 1907). Records from that original survey exist and were examined in the current study at the John D. Rockefeller, Jr. Library (Special Collections) in Colonial Williamsburg. Bland laid out an orthogonal grid of streets and boundaries with the magnetic bearings of N00.25 $\mathrm{W}$ and $\mathrm{N} 89.75^{\circ} \mathrm{E}$ (Goodwin, 1980). By comparing bearings with respect to True North observed using Google Earth Pro with the magnetic bearings recorded by Theodorick Bland for the original western boundary $\left(\mathrm{N} 00.25^{\circ} \mathrm{W}\right.$ defined by Boundary Street) and the original main street $\left(\mathrm{N} 89.75^{\circ} \mathrm{E}\right.$ along Duke of Gloucester Street), the 1699 magnetic declination at Williamsburg was inferred to have been $3.31^{\circ} \mathrm{W}$ (Appendix IV), which is in good agreement with the gufm 1 model $\left(3.62 \pm 0.50^{\circ} \mathrm{W}\right)$. Archaeological data have demonstrated that those streets are in their original 1699 locations (e.g., Brown et al., 1990; Goodwin, 1980). Measurements of these same two streets using LiDAR images yielded a value for the 1699 declination of $3.33^{\circ} \mathrm{W}$ (Appendix IV).

The potential for using old streets to infer magnetic declinations was originally suggested by Bauer (1902; p. 42). Although high-resolution LiDAR images of Williamsburg were not required since the two streets are not obscured by a forest canopy, the inferred values for the 
1699 magnetic declination in Williamsburg, VA from Google Earth Pro $\left(3.31^{\circ} \mathrm{W}\right)$ and LiDAR images $\left(3.33^{\circ} \mathrm{W}\right)$ were in excellent agreement (Appendix IV).

\subsection{Synthesis}

The extensive data-base that was compiled (Jonkers et al., 2003) to develop the gufm1 model (Jackson et al., 2000) was principally derived from ships' logs, whereas the current study used an independent approach using exclusively land-based locations. Comparisons of magnetic declinations determined in this study with those from the NCEI calculator (gufm1: Jackson et al., 2000; Jonkers et al., 2003; IGRF12: Thebault et al., 2015) and USHD models are shown in Figures 6a-c. Within the measured precisions of the stone wall-defined boundaries reported here, and the estimated $0.5^{\circ}$ uncertainty in the gufm 1 model (Jackson et al., 2000; Jonkers et al., 2003), the agreements are excellent in the interval 1685-1900, except for the $\sim 35$-year interval of 1775-1810. During that brief interval, the stone walls located along surveyed boundaries suggest that the magnetic declinations were up to $1.5^{\circ}$ eastward of the gufm 1 values in the studied locations (Figure 7a). This current study also indicates that the magnetic declinations in 1750-1780 were up to $2.0^{\circ}$ westward of the USHD values (Figure $7 \mathrm{~b}$ ).

Figure 7: Differences (degrees) in the magnetic declinations determined in the current study of all locations at times of dated land surveys in New Hampshire, New York, and Virginia with

magnetic declinations from (a) gufm1 and IGRF12 models, (b) USHD model, and (c)

combination. The typical uncertainty of the new data (based on the precision of the measurements; Table 1) is shown in the lower left corner of the figure. Positive and negative values on the $y$-axis indicate that the magnetic declinations determined in this study were more eastward and more westward, respectively, than the values in the gufm1, IGRF12, and USHD models. The horizontal lines at $\pm 0.5^{\circ}$ are the estimated range of uncertainties in the gufm 1 values for the interval 1590-1900 (Jackson et al., 2000; Jonkers et al., 2003).

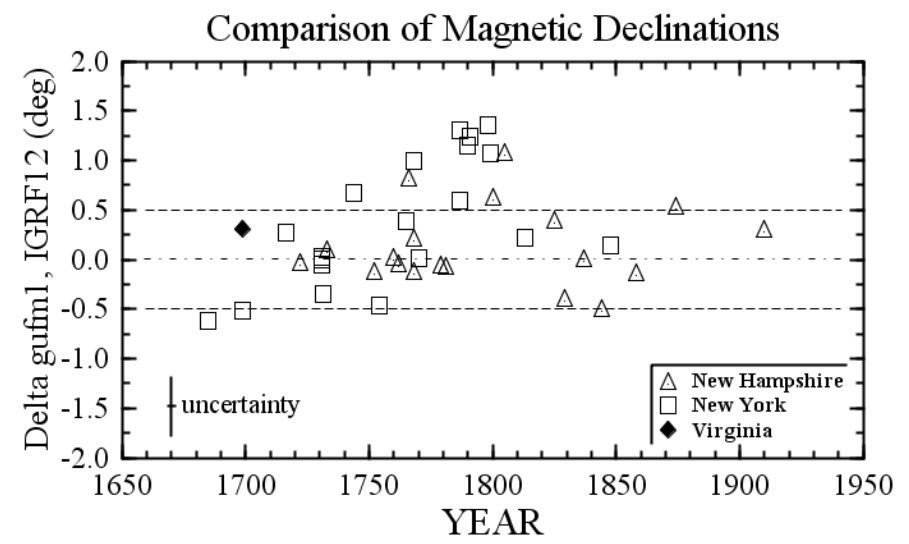

(a) 


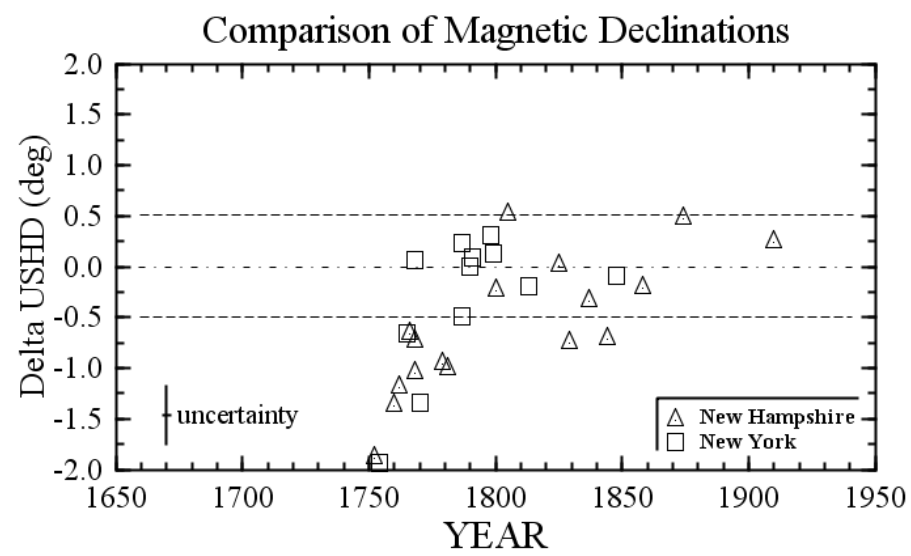

(b)

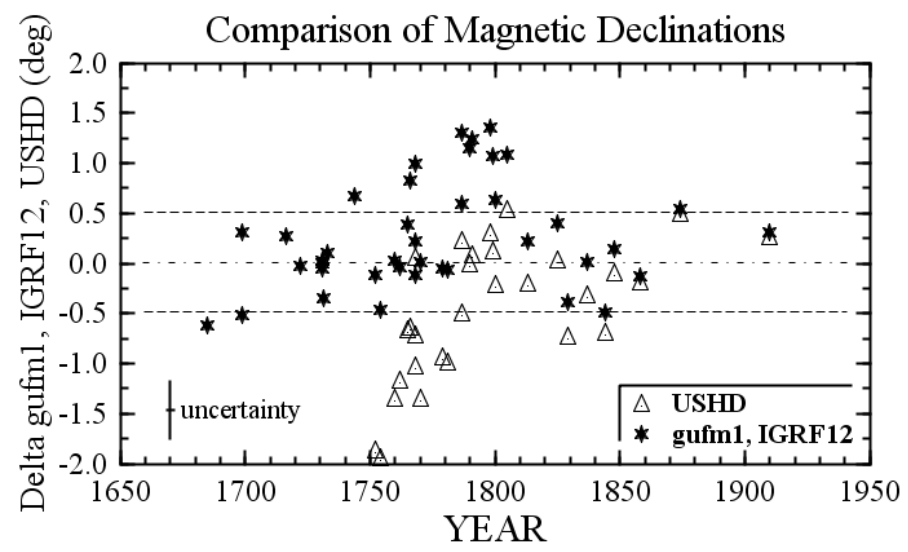

(c)

Bauer (1902) provided a compilation of magnetic declinations that were measured in the $18^{\text {th }}$ and $19^{\text {th }}$ centuries at many locations in New Hampshire and New York. Although the scatter of the Bauer (1902) data is greater than the data reported in the current study, those data are also broadly consistent with the values predicted by the gufm1 and IGRF12 models (Figure 8). In agreement with results from the current study, the Bauer (1902) declinations consistently show magnetic declinations that were about $2.0^{\circ}$ eastward of the gufm 1 values in 1780-1800 (Figure 7). While local crustal magnetic anomalies must contribute to deviations between declinations measured in this study and the geomagnetic models (e.g., Figure 7a), the systematic offset of declinations from the gufm1 model in this brief interval (1775-1810) across sites in New York and New Hampshire are interpreted as being small, but real, deviations from the values predicted by the gufm 1 model.

As noted in section 3.4, and briefly mentioned by Bauer (1902; p. 42), the orientations of old streets, such as those in Colonial Williamsburg, VA measured in the current study, can also be used to constrain magnetic declinations when accurate historical information exists. Highresolution LiDAR images would not be required for those measurements.

Figure 8: Differences (degrees) in the magnetic declinations measured in New Hampshire and New York (Bauer, 1902) with values predicted by the gufm1 and IGRF12 models. Note the prominent cluster of positive values in the vicinity of 1800 indicating that magnetic declinations were about 1 to $2^{\circ}$ less westward than the predicted gufm 1 values. The current study also 
showed a similar result (Figure 7a). The data from Bauer (1902) were in two groups. Group I data (1) were acquired at locations that were accurate to within 1-minute of latitude and 2minutes of longitude. Group II data (2) were acquired at locations supplied by county surveyors, and/or listed on US Geological Survey topographic maps.

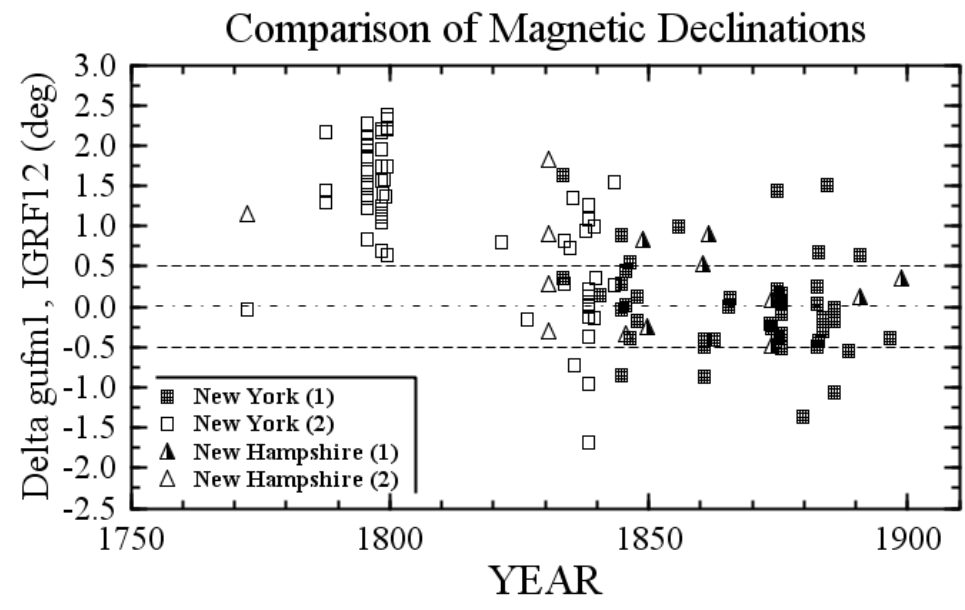

\section{Conclusions}

[a] Old land surveys in glaciated regions of the northeastern United States have been used in combination with high-resolution LiDAR images to measure old stone walls that were built along boundaries defined by surveyors using magnetic compasses. The angular precisions (e.g., better than $0.5^{\circ}$ ) measured in the current investigation among those $17^{\text {th }}$ and $18^{\text {th }}$ century surveys reflect the expertise of some survey teams in that period.

[b] Good agreement was observed between the land-based results independently obtained using stone walls in this study and principally navigational logs from ships at sea (gufm1: Jackson et al., 2000; Jonkers et al., 2003). Small, systematic differences in declinations were observed in the interval of 1775-1810 that may warrant small updates in the gufm 1 model and in the interval 1750-1800 for the USHD model.

[c] Although some of the specific regions examined in this study measured $>100 \mathrm{~km}$ of stone wall-defined boundaries, lengths of individual boundaries with lengths $>5 \mathrm{~km}$ were generally found to yield consistent results (Figure 3). Future investigations who may use this approach should, however, measure many boundaries in a locality to assess the quality of the original surveys.

[d] Since old stone walls are a common feature in many other areas that had early agrarian settlements (e.g., Canada; England; Ireland; Scotland; vast areas of Europe), it seems reasonable to expect that this approach has the potential for yielding a trove of high-quality information on magnetic declinations in regions of Europe and Asia wherever records of old, high-quality land surveys that used magnetic compasses have been preserved. 
[e] Other kinds of durable, human-engineered structures on the Earth's surface can also be valuable in geomagnetic studies. As originally noted by Bauer (1902; p. 42), old streets in early settlements (e.g., this study of Colonial Williamsburg, VA in 1699) with extensive historical documentation (e.g., high-quality land surveys; archaeological data) can yield reliable geomagnetic data.

\section{Acknowledgments}

Comments from two anonymous reviewers were constructive and insightful. Prof. Alexander Buyantuev in the Dept. of Geography and Planning provided early instruction with processing LiDAR images. Personnel at the New York State Archives in Albany, NY and the New Hampshire State Archives in Concord, NH are thanked for providing the author with copies of $18^{\text {th }}$ century land surveys. Mr. Frank J. Doherty kindly provided copies of his comprehensive work on the history of the Beekman Patent. Anne Valente, Sharon Martin Zankel, and Stacy Broderick at the Brunswick Historical Society provided important $18^{\text {th }}$ century documents about Brunswick, NY. Ned and Regina Howe of Brunswick, NY are thanked for providing permission in 2015 for the author to explore the late $18^{\text {th }}$ century stone walls on their land, which ultimately led to this project being expanded. Dr. Dale F. Bloom provided helpful comments on an earlier version of this paper. The author's orange tabby, Jasper, was a devoted friend and constant companion, who 'oversaw' much of this work from his favorite place next to the computer.

The author confirms that there are no real or perceived conflicts of interest associated with this work.

Data compiled in Appendices I-IV are available under the file name 'Geomagnetic Declination' at the following site: https://scholarsarchive.library.albany.edu/do/search/?q=author_lname\%3A\%22Delano\%22\%20 AND\%20author_fname\%3A\%22John\%22\&start=0\&context $=5661620 \&$ sort $=$ date desc \&facet $=$.

\section{References}

Allport, S. (1990) Sermons in Stone: The Stone Walls of New England and New York. W. W. Norton \& Co., New York. 205pp.

Baird, C. W. (1871) Chronicle of a Border Town: History of Rye, Westchester County, New York 1660-1870. Anson D. F. Randolph \& Co., New York. 612pp.

Barron, H. S. (1984) Those Who Stayed Behind: Rural Society in Nineteenth Century New England. Cambridge University Press, New York. 184pp.

Batchellor, A. S. (1891) Provincial Papers of New Hampshire. Vol. XIX, John B. Clarke, Public Printer, Manchester, NH. 772pp.

Batchellor, A. S. (1895) Town Charters granted within the Present Limits of New Hampshire, Vol. XXV, Edward N. Pearson, Public Printer, Concord, NH. 868pp.

Batchellor, A. S. (1896a) Township Grants of Lands in New Hampshire included in the Masonian Patent Issued Subsequent to 1746 by the Masonian Proprietary. Vol. XXVII, Edward N. Pearson, Public Printer, Concord, NH. 680 pp.

Batchellor, A. S. (1896b) Town Grants of Lands in New Hampshire. Vol. XXVIII, Edward N. Pearson, Public Printer, Concord, NH. 868 pp.

Batchellor, A. S. (1896c) Documents relating to the Masonian Patent 1630-1846. Vol. XXIX, Edward N. Pearson, Public Printer, Concord, NH. 736pp. 
Bauer, L. A. (1902) U.S. Magnetic Declination Tables and Isogonic Charts for 1902 and Principal Facts relating to the Earth's Magnetism. U.S. Coast and Geodetic Survey, U.S. Gov't Printing Office, Washington, D.C. 438pp.

Bouton, N. (1856) The History of Concord, From its First Grant in 1725 - To the Organization of the City Government in 1853, with a History of the Ancient Penacooks. Benning W. Sanborn, Concord, NH.

Bouton, N. (1875) Documents and Records relating to Towns in New Hampshire. Volume IX, Charles C. Pearson, State Printer, Concord, NH. 998pp.

Bowen, C. W. (1882) The Boundary Disputes of Connecticut. James R. Osgood \& Co., Boston. 206pp.

Bowles, O. (1939) Chapter 12: Boulders as building material, in The Stone Industries (2 ${ }^{\text {nd }}$ ed.). p. 296-300. McGraw-Hill Book Company, Inc. New York. 544pp.

Brown, G. J., Higgins, T. F. III, Muraca, D. F., Pepper, S. K., Polk, R. H., Gaynor, J. B., and Pittman, W. E. (1990) Shields Tavern archaeological report, Block 9 Building $26 B$.

Colonial Williamsburg Library Research Report Series -1626. Williamsburg, VA. 253pp.

Buck, C. and McDermott, W. P. (1979) Eighteenth Century Documents of the Nine Partners Patent Dutchess County New York. Gateway Press, Baltimore. 774pp.

Chase, F. (1891) A History of Dartmouth College and the Town of Hanover, New Hampshire. Volume 1, (John K. Lord, ed.). John Wilson and Son, University Press. 714pp.

Coffin, C. C. (1878) The History of Boscawen and Webster from 1733 to 1878. Republican Press Association, Concord, NH. 872pp.

Cogswell, L. W. (1880) History of the Town of Henniker, Merrimack County, New Hampshire, from the date of the Canada Grant by the Province of Massachusetts, in 1735, to 1880. Republican Press Association, Concord, NH. 868pp.

Colonial Williamsburg Foundation (2014) Colonial Williamsburg: The Official Guide by the Colonial Williamsburg Foundation. Colonial Williamsburg Foundation, Williamsburg, VA.

Connecticut Department of Transportation Survey Operations (1997) 1997 Connecticut-New York Boundary Line Perambulation, Bounds 1-87, Book “A”. Connecticut Department of Transportation. 165pp.

Cowles, G. W. (1895) Landmarks of Wayne County, New York. D. Mason \& Co. Publishers, Syracuse, New York. 343pp.

Dearborn, J. J. (1890) The History of Salisbury, NH from the Date of Settlement to the Present Time (James O. Adams and Henry P. Rolfe, eds.). William E. Moore, Manchester, NH. 994pp.

Dodge, J. G. (1885) History of Windsor, in History of Hillsborough County (D. Hamilton Hurd, ed.), p. 725-729. J. W. Lewis Co., Philadelphia, PA. 1164pp.

Doherty, F. J. (1998) Settlers of the Beekman Patent, Dutchess County, New York: A Genealogical and Historical Study of the all the $18^{\text {th }}$ Century Inhabitants of the Patent.

Vol. II. New England Historic and Genealogical Society, Boston, MA.

Foster, D. R. (1992) Land-use history (1730-1990) and vegetation dynamics in central New England, USA. J. Ecol., 80, 753-772.

Gannett, H. (1896) Magnetic declination in the United States. U. S. Geol. Survey, $17^{\text {th }}$ Annual Rept., Washington, DC. 237pp. 
Gannett, H. (1900) Boundaries of the United States and of the Several States and Territories with an Outline of the History of all Important Changes of Territory. U. S. Geol. Survey Bulletin 171 ( $2^{\text {nd }}$ ed.), U.S. Gov’t Printing Office, Washington. 435pp.

Gibbs, A. S. (1897) Harpersfield, in Delaware County, New York: History of the Century 17971897 (David Murray, ed.), p. 415-459. William Clark Publisher, Delhi, NY. 628 pp.

Goodwin, R. (1980) A Brief and True Report concerning Williamsburg in Viriginia. August and Charles Deetz, Richmond, VA. 406pp.

Gould, I. (1897) History of Stoddard, Cheshire County, N.H. W. L. Metcalf, Steam Job Printer, Marlboro, NH. 154pp.

Hammond, I. W. (1884) Documents relating to Towns in New Hampshire: New London to Wolfeborough, Vol. XIII, Parsons B. Cogswell, Public Printer, Concord, NH. 892pp.

Harrison, B. (2005) Tourism, farm abandonment, and the 'typical' Vermonter, 1880-1930. J. Hist. Geog., 31, 478-495.

Hasbrouck, F. (1909) History of Dutchess County, New York. S. S. Matthieu, Poughkeepsie, NY. 1077pp.

Hening, W. W. (1823) Statutes at Large: being a collection of all laws of Virginia, from the first session of the legislature, in the year 1619. Vol. III. Thomas Desilver, Philadelphia, PA. $612 \mathrm{pp}$.

Huntting, I. (1897) History of Little Nine Partners of Northeast Precinct, and Pine Plains, New York, Dutchess County. Chas. Walsh \& Co., Amenia, NY. 432pp.

Hurd, D. H. (1886) History of Cheshire and Sullivan Counties, New Hampshire. J. W. Lewis \& Co., Philadelphia, PA. 1156pp.

Jackson, A., Jonkers, A. R. T., \& Walker, M. R. (2000) Four centuries of geomagnetic secular variation from historical records. Phil. Trans. R. Soc. London, 358, 957-990.

Johnson, K. M. \& Ouimet, W. B. (2014) Rediscovering the lost archaeological landscape of southern New England using airborne light detection and ranging (LiDAR). J. Archaeol. Sci., $\underline{43}, 9-20$.

Johnson, K. M. \& Ouimet, W. B. (2016) Physical properties and spatial controls of stone walls in the northeastern USA: implications for Anthropocene studies of 17 th to early 20th century agriculture. Anthropocene, $\underline{15}, 22-36 .$.

Jonkers, A. R. T., Jackson, A., and Murray, A. (2003) Four centuries of geomagnetic data from historical records. Rev. Geophys., 41, 1006-1043.

Kopper, P. (1986) Colonial Williamsburg. Harry N. Abrams, New York.

Livermore, A. A. \& Putnam, S. (1888) History of the Town of Wilton, Hillsborough, New Hampshire with a Genealogical Register. Marden and Rowell Printers, Lowell, MA. 718 pp.

Lyford, J. O. (1912) History of the Town of Canterbury, New Hampshire: 1727-1912. Vol. 1. Mumford Press, Concord, NH. 556pp.

Maar, C. (1926) Origin of the classical place names in central New York. Quart. J. New York State Hist. Assoc., 7(3), 155.

McDermott, W. P. (1986) Colonial Land Grants in Dutchess County, NY: A Case Study in Settlement. Hudson Valley Regional Rev., $\underline{3}$ (2), 19pp.

Oxford Publishing Company (1912) Historical and Genealogical Record, Dutchess and Putnam Counties, New York. A. V. Haight Co., Poughkeepsie, NY. 610pp.

Nissenson, S. G. (1937) The Patroon's Domain. Columbia University Press, New York. 416 pp. 
Pelletreau, W. S. (1886) History of Putnam County, New York, with Biographical Sketches of its Prominent Men. W. W. Preston \& Co., Philadelphia. 1010pp.

Pierce, G. M. (1909) The military tract of New York State. The New York Genealogical and Biographical Record, $\underline{40}$ (1), 15.

Primack, M. L. (1969) Farm fencing in the nineteenth century. J. Econ. History, 29 (2), p. 287291.

Proper, D. R. (1974) A narrative of Stoddard, New Hampshire, in The History of Stoddard, New Hampshire (R. W. Newell, ed.). p. 1-50. Stoddard Historical Society, Stoddard, NH. $351 \mathrm{pp}$.

Raup, H. M. \& Carlson, R. E. (1941) The history of land use in the Harvard Forest. Harvard Forest Bulletin No. 20, 74pp.

Schein, R. H. (1993) Framing the frontier: The new military tract survey in central New York. New York History, 74 (1), 4-28.

Smith, P. H. (1877) General History of Duchess County, from 1609 to 1876, Inclusive. Philip H. Smith, Pawling, NY. 526pp.

Stein, M. (2008) How the States got their shapes. HarperCollins Publishers, New York. 334pp.

Struthers, P. H. (1968) A History of Nelson, New Hampshire 1767-1967. The Sentinel Printing Co., Inc. 298pp.

Sylvester, N. B. (1880) The History of Rensselaer Co., New York. Everts and Peck, Philadelphia. $844 \mathrm{pp}$.

Thébault, E., Finlay, C. C., Beggan, C. D., Alken, P., Aubert, J., Barrois, O., Bertrand, F., Bondar, T., Boness, A., Brocco, L., Canet, E., Chambodut, A., Chulliat, A., Coïsson, P., Civet, F., Du, A., Fournier, A., Fratter, I., Gillet, N. Hamilton, B., Hamoudi, M., Hulot, G., Jager, T., Korte, M., Kuang, W., Lalanne, X., Langlais, B., Léger, J.-M., Lesur, V., Lowes, F. J., Macmillan, S., Mandea, M., Manoj, C., Maus, S., Olsen, N., Petrov, V., Ridley, V., Rother, M., Sabaka, T. J., Saturnino, D., Schachtschneider, R., Siro, O., Tangborn, A., Thomson, A., Tøffner-Clausen, L., Vigneron, P., Wardinski, I., and Zvereva, T. (2015) International Geomagnetic Reference Field: the 12th generation. Earth, Planets and Space, $\underline{67}, 79-98$.

Thorson, R. M. (2002) Stone By Stone: The Magnificent History in New England's Stone Walls. Walker \& Co., New York. 287pp.

Tyler, L. G. (1907) Williamsburg, the old colonial capitol. Whittet and Shepperson, Richmond, VA. 286pp.

Wilson, P. (1974) Early Stoddard families, in The History of Stoddard, New Hampshire (R. W. Newell, ed.). p. 276-319. Stoddard Historical Society, Stoddard, NH. 351pp. 